\title{
Ventricular septal defect
}

\section{Incidence, morbidity, and mortality in various} age groups

\author{
J. D. Keith, V. Rose, G. Collins, and B. S. L. Kidd \\ From The Hospital for Sick Children, 555 University Avenue, \\ Toronto 2, Ontario, Canada
}

The true incidence of isolated ventricular septal defect and its subdivisions is difficult to estimate accurately, since the data available in the past have been obtained in a variety of incomplete ways. Necropsy studies usually included the complicated as well as the isolated cases. The clinical diagnostic criteria were less accurate than those used currently. Some studies dealt only with adults; other reports omitted infants or took patients into the investigation series at different ages.

It is reasonable to conclude that no final figures will ever be arrived at, since the factors affecting prevalence data are changing continuously and no two studies are identical or complete. However, it is worth while considering some of the information obtained in the past from certain specific points of view.

\section{Pathological data}

Table I presents four references on the incidence of ventricular septal defect at necropsy.

TABLE I Ventricular septal defect: incidence at necropsy

\begin{tabular}{ll}
\hline Authors & $\begin{array}{l}\text { Rate per 1000 } \\
\text { necropsies }\end{array}$ \\
\hline Gelfman and Levine (1942) & $\mathrm{I} \cdot 0$ \\
Selzer (1949) & 0.40 \\
Kaplan et al. (1961) & 0.65 \\
Bloomfield (1964) & 0.57 \\
\hline
\end{tabular}

Since the majority of infants with ventricular septal defect survive, and many have the defect closed spontaneously, it is obvious that the necropsy data do not give a true picture of the prevalence of this anomaly in the population as a whole. It is clearly important to estimate incidence very early in life to arrive at a satisfactory figure. Two references attempt to achieve this (see Table 2).

1 These investigations were supported by a grant from the Ontario Heart Foundation.
TABLE 2 Ventricular septal defect: incidence in live births

\begin{tabular}{ll}
\hline Authors & Rate per I0oo \\
\hline Hoffman and Rudolph (1965) & I \\
Rose and Keith (1970) & I.37 \\
\hline
\end{tabular}

There are a few factors that might operate from time to time to increase the incidence of ventricular septal defect, such as rubella. As far as we can tell from the statistics in the Toronto Heart Registry, the prevalence of ventricular septal defects remains about the same from year to year and rubella or other infections have a minimal or minor role. The true incidence, therefore, appears to be somewhere between $I / 700$ and I/1000 live births as shown in Table 2.

Ventricular septal defect is the most common heart anomaly in childhood, comprising approximately 25 per cent of all congenital heart disease as an isolated defect, but it occurs in 50 per cent of congenital heart disease if all complex forms are included. Among infants dying with congenital heart disease in the first month of life, ventricular septal defect is second only to transposition of the great arteries as a cause of death in this age group (Keith, Rowe, and Vlad, 1967; Keith et al., I970).

\section{Present study}

The present study is an attempt to arrive at a clearer recognition of the true prevalence of ventricular septal defect and the various responses to it of the human body.

Our records now include approximately I500 cases of infants, children, and adults with isolated ventricular septal defect. The group that offers the best appraisal of the course followed by these children is that which starts in the first year of life and in which follow-up has occurred over many years. We have 630 in this category. Some 318 were diag- 
nosed clinically on the basis of a well-heard blowing systolic murmur over the lower praecordium without a thrill, and with the passage of time the presence of aortic stenosis, pulmonary stenosis, or patent ductus arteriosus was ruled out. Those in whom there appeared to be any doubt about the diagnosis were catheterized. Thus we have 318 diagnosed clinically and an additional 312 diagnosed by catheterization, giving a total of 630 seen first in the first year of life.

In an attempt to evaluate our experience most profitably we have divided our patients into 4 groups:

(A) A group of 200 infants catheterized in the first year of life and in the majority of cases recatheterized some years later.

(B) A group of 112 that were catheterized at various ages for diagnostic purposes but all seen initially in the first year of life.

(C) A group of 318 infants seen first in the first year of life whose findings satisfied the criteria for diagnosis of ventricular septal defect as listed above but on whom no catheter studies were performed. This group consisted chiefly of small defects for which detailed studies did not appear to be necessary. From our experience over the years with many similar small defects investigated in the past in complete detail, we have arrived at a conclusion that the diagnosis can be substantiated clinically with at least 95 per cent accuracy. We feel that it is important to include this benign group, since without it a very lopsided picture of the severity and incidence of the complications would be obtained. Thus, when groups $A, B$, and $C$ are put together we have 630 cases of isolated ventricular septal defect seen first in the first year of life. To date they have now been followed an average of 7.5 years.

(D) A group of 295 cases of isolated ventricular septal defect, now in the teenage or adult category, is being followed. Initially they were all seen in infancy or childhood at The Toronto Hospital for Sick Children. All in this group were born before 1955, and have a follow-up of 16 to 42 years.

\section{Group A}

The 200 infants catheterized in the first year of life were divided into 6 haemodynamic groups according to the classification of Kidd et al. (1965). The groups are as follows: (I) pulmonary to systemic flow ratio of less than 2: I and a normal pulmonary vascular resistance; (II) pulmonary to systemic flow ratio of greater than 2:I with a normal pulmonary vascular resistance; (III) pulmonary to sys- temic flow ratio greater than $2: 1$ with slight increased resistance; (IV) pulmonary to systemic flow ratio greater than 2:I with a moderate increase in resistance; (V) pulmonary to systemic flow ratio of less than $2:$ I with high pulmonary vascular resistance but no reversal of flow; and (VI) pulmonary to systemic flow ratio of less than 2: I with high pulmonary vascular resistance and reversal of flow through the defect (Eisenmenger syndrome).

The haemodynamic groups at the start of observation in the first year of life and at follow-up are shown in Table 3 (for group A only).

TABLE 3 Group A: infant catheter studies in ventricular septal defect

\begin{tabular}{|c|c|c|c|c|c|c|c|c|}
\hline \multirow{2}{*}{$\begin{array}{l}\text { Haemo- } \\
\text { dynamic } \\
\text { group at } \\
\text { start }\end{array}$} & \multirow[t]{2}{*}{$\begin{array}{l}\text { Total } \\
\text { cases }\end{array}$} & \multicolumn{6}{|c|}{$\begin{array}{l}\text { Haemodynamic group } \\
\text { at follow-up }\end{array}$} & \multirow[t]{2}{*}{ Other } \\
\hline & & I & II & III & IV & $\mathbf{V}$ & VI & \\
\hline $\begin{array}{l}\text { I } \\
\text { II } \\
\text { III } \\
\text { IV } \\
\text { V }\end{array}$ & $\begin{array}{l}43 \\
64 \\
46 \\
36 \\
11\end{array}$ & $\begin{array}{r}39 \\
33 \\
14 \\
8 \\
7\end{array}$ & $\begin{array}{r}4 \\
16 \\
4 \\
5 \\
1\end{array}$ & $\begin{array}{l}0 \\
1 \\
7 \\
6 \\
1\end{array}$ & $\begin{array}{l}0 \\
2 \\
6 \\
5 \\
0\end{array}$ & $\begin{array}{l}0 \\
2 \\
0 \\
1 \\
0\end{array}$ & $\begin{array}{l}0 \\
0 \\
3 \\
2 \\
0\end{array}$ & $\begin{array}{r}0 \\
10 \\
12 \\
9 \\
2\end{array}$ \\
\hline Total & 200 & IOI & 30 & I5 & 13 & 3 & 5 & 33 \\
\hline
\end{tabular}

Initial catheter first year of life.

Haemodynamic group A I Ninety per cent of those that started in group A I remained in group A I - none developed pulmonary infundibular stenosis, none died, none required surgery, and there was no increase in pulmonary vascular resistance. This is obviously a very benign group compared with the others. At the end of this follow-up in the total group of 200 cases there were IOI that eventually fell into group A I, indicating the recognized tendency of a ventricular septal defect to decrease in size and decrease the flow through it (see Table 3).

Haemodynamic group A II There were 64 cases initially in this category, but on follow-up only 25 per cent persisted in group II; 5I per cent became group $I$, and the rest were scattered over the other categories as shown in Table 3. Five, or 9 per cent, developed pulmonary infundibular stenosis, 17 per cent died, 23 per cent required surgery, and 5 per cent had a conspicuous increase in pulmonary vascular resistance. It is of special interest that about half of these cases ended up in group A I after starting in group A II.

The relatively high incidence of deaths and surgery indicates the presence of intractable heart failure that one associates with a large 
defect. There is always the problem of how long one should treat these infants medically in the hope that the failure will be controlled or the defect will get smaller, or both. The relatively high incidence of deaths and surgery in groups II, III, and IV indicated the lack of conspicuous success in medical or surgical treatment in many instances.

Haemodynamic group A III The cases seen initially in group A III have a relatively serious prognosis. Only 30 per cent decreased in size to end up in group A I. Three cases, or 6 per cent, developed pulmonary infundibular stenosis, 20 per cent died, 43 per cent required surgery, and 20 per cent ultimately developed a conspicuous increase in pulmonary vascular resistance.

Haemodynamic group A IV This group also has a serious prognosis. Only 22 per cent decreased to group I, 25 per cent died, 50 per cent had surgery related to the heart, and 22 per cent developed a high pulmonary vascular resistance.

Haemodynamic group A V This group appears to be relatively benign. Seven of the II cases ended up in group I. One case died and one required surgery. All had a decline of the pulmonary vascular resistance to normal levels. This group therefore appears to have persistence of the foetal pulmonary vascular response after birth which lasts for several months but declines in the latter half of the first year of life. We think that one can reasonably conclude that these are either small defects to begin with, or become so in the first year or two of life, and therefore usually have a favourable response in spite of the initial high resistance of the lung fields.

Haemodynamic group A VI (see Table 3) These cases were obviously not in group VI in the first year of life, since it takes several years before fully developed pulmonary vascular disease occurs in isolated ventricular septal defect. It may occur more rapidly in transposition of the great vessels than in ventricular septal defect. However, at the end of 7 years, 5 cases could legitimately be put in the category of Eisenmenger syndrome with reversal of flow through the defect.

Other The cases listed under the heading of 'Other' in Table 3 are those in which it was not possible to do a second catheterization either because they were operated on or treated medically and died or, in a few cases, were lost to follow-up.
Deaths in group $\mathbf{A}$ These occurred almost entirely in haemodynamic groups II, III, and IV, and were due to heart failure, or failure plus respiratory infection, or unsuccessful surgery whether this was of direct closure type or banding of the pulmonary artery to control excessive pulmonary blood flow. Group A cases had more severe or larger defects than the other groups, hence the higher mortality (see Table 4, and Table 8 which shows the overall mortality of the whole group of 630 children).

TABLE 4 Infant catheter study: deaths by haemodynamic group in group $A$ (200 infants with repeat catheter studies)

\begin{tabular}{llc}
\hline Group & No. in group & Deaths \\
\hline I & 43 & 0 \\
II & 64 & I $(17 \%)$ \\
III & 46 & $9(20 \%)$ \\
IV & 36 & $9(25 \%)$ \\
V & II & I (9\%) \\
\hline Total & 200 & $30(15 \%)$ \\
\hline
\end{tabular}

\section{Development of infundibular pulmonary stenosis}

Since Gasul, Dillon, and Vrla in 1957 first described the development of infundibular stenosis in a child who had previously had an isolated ventricular septal defect, a number of investigators have attempted to determine the true incidence of this developing complication. As we have shown, it appears to vary with the haemodynamic group concerned. It did not occur in haemodynamic groups I, V, or VI. It did occur in 6 to II per cent of the cases in groups A II, A III, and A IV (those that had a flow ratio greater than 2:I with or without some increase in resistance). The gradient at the time of first catheter was minimal or absent in the 13 cases recorded here. At the end of the follow-up period the gradient varied from 15 to $80 \mathrm{~mm}$. $\mathrm{Hg}$. Two cases by that time were classified as typical tetrad of Fallot and were operated on. The initial gradient in each had been less than Io mm. Hg.

Recently Tyrrell et al. have presented data on 22 cases at The Toronto Hospital for Sick Children which initially had gradients across the pulmonary valve of less than $20 \mathrm{~mm}$. $\mathrm{Hg}$, and all increased significantly with follow-up (Tyrrell et al., 1970). Two were identified as due to anomalous right ventricular muscle bundle and the others had the usual type of infundibular stenosis in the outflow tract. 


\section{Pulmonary vascular resistance}

One of the long-term complications of the ventricular septal defect is the development of progressive increase in pulmonary vascular resistance until there is reversal of flow through the defect and a resultant drop in the arterial oxygen saturation. In time cyanosis appears and the full-blown picture of the Eisenmenger syndrome is complete. The natural history of such cases leads to death, usually in the teens or twenties, but some survive to the thirties or forties.

The data indicated above reveal that such cases do not come from haemodynamic group I but evolve from group II, III, or IV, eventually presenting with the flow and resistance patterns seen in group A VI. Infants in group $\mathrm{A} \mathrm{V}$ in the first year of life with isolated ventricular septal defect appear to resolve their raised pulmonary resistance and end up with a benign prognosis. Any child with a flow greater than 2:I in early life should be seen by a physician at regular intervals, repeating the radiograph and electrocardiogram at each visit. If there is increasing right ventricular hypertrophy in the electrocardiogram and decreasing size of heart in the radiograph the cardiac catheter study should be repeated. Early operation is imperative in many such cases before the pulmonary vascular changes become irreversible. Most children with 2:I flow ratio and rising resistance will respond favourably if operated on by 2 years, either by direct closure or banding of the pulmonary artery. If it is left until 5 years there will be some who are certain to progress to fatal outcome in spite of adequate surgery.

For those who have a low pulmonary resistance and increased flow in childhood, operation can be postponed until it becomes clear whether the defect is getting smaller, but if a relatively high flow continues such cases may ultimately develop pulmonary vascular disease at a later age, as happens in some cases of atrial septal defect in the second, third, or fourth decade. Direct closure is therefore indicated between 5 and ro years of age if flow ratio is persistently greater than $2: I$.

\section{Combined infant groups $A, B$, and $C$ at follow-up}

As indicated earlier, we have 630 infants seen in the first year of life and followed up for an average of 7.5 years or more in categories $A, B$, and $C$.

A summary of the haemodynamic groups in the 630 cases at the most recent follow-up is given in Table 5 .

There are 3 main divisions, those that had
TABLE 5 Haemodynamic groups: categories $A, B$, and $C$ at latest follow-up

\begin{tabular}{lcrrr}
\hline $\begin{array}{l}\text { Haemo- } \\
\text { dynamic } \\
\text { group }\end{array}$ & $\begin{array}{l}\text { Catheter } \\
\text { and } \\
\text { surgery }\end{array}$ & $\begin{array}{l}\text { Catheter } \\
\text { alone }\end{array}$ & $\begin{array}{l}\text { Clinical } \\
\text { evalua- } \\
\text { tions }\end{array}$ & Totals \\
\hline I & I & 143 & 292 & $437(71 \%)$ \\
II & 21 & 42 & 25 & $88(14 \%)$ \\
III & 64 & 11 & I & $75(12 \%)$ \\
IV & 15 & 9 & 0 & $24(4 \%)$ \\
V & 2 & 2 & 0 & $4(0.6 \%)$ \\
VI & I & I & 0 & $2(0.3 \%)$ \\
\hline Total & IO4 & 208 & 318 & 630 \\
\hline
\end{tabular}

both catheter studies and surgery (the most serious cases), those that had catheter studies but surgery was not carried out (an intermediate group), and finally the most benign category - those in whom no catheter study or operation was carried out.

As might be expected, those operated on were chiefly in haemodynamic groups II to IV (high flow), whereas those who had no surgery were chiefly in haemodynamic group I (low flow), although a few were found to be in group II (high flow, low resistance).

Another striking difference between the three categories was the incidence of spontaneous closure of the defect. There was of course no spontaneous closure in the surgical group. In the non-surgical catheter study group II per cent, and in the clinical group 26 per cent closed spontaneously.

\section{Spontaneous closure}

There are a variety of figures given in the literature of the last 2 to 12 years on the incidence of spontaneous closure of the ventricular septal defect. Four of these are shown in Table 6.

TABLE 6 Spontaneous closure of ventricular septal defect

\begin{tabular}{ll}
\hline Authors & Percentage closing \\
\hline Keith, Rowe, and Vlad (1958) & 10 \\
Hoffman and Rudolph (1965) & 24 \\
Ash (1964) & 15 \\
Li et al. (1969) & 22 \\
\hline
\end{tabular}

The present report summarizes 2 groups:

(I) The 630 cases followed from infancy for an average of 7.5 years with an overall closure rate of 17 per cent (Table 7). The small defects identified clinically had the highest closure rate $(26 \%)$.

(2) Among the 295 cases followed through the teens into the twenties 4 per cent closed spontaneously (see Table IO). It will 
TABLE 7 Spontaneous closure

\begin{tabular}{llc}
\hline Group & $\begin{array}{l}\text { No. of } \\
\text { cases }\end{array}$ & $\begin{array}{l}\text { No. of spontaneous } \\
\text { closures }\end{array}$ \\
\hline Catheter and surgery & 104 & 0 \\
Catheter study only & 208 & $22(11 \%)$ \\
Clinical & 318 & $82(26 \%)$ \\
\hline Total & 630 & $104(17 \%)$ \\
\hline
\end{tabular}

be necessary to follow the infant group through the teens and re-evaluate the adult group from time to time to arrive at a more final figure. However, it is quite suitable for the moment to add the 17 per cent closure in the first 7 years of life to the 4 per cent of the post-childhood group, giving a total of 21 per cent. This would appear to be a minimum figure which will rise with the passage of time the longer a group of patients is followed.

Perhaps equally important is to recognize early in life which cases are likely to close of their own accord, particularly in the first year or two of life. It is obvious that this is most likely to occur in the smaller defects, since approximately 30 per cent of the cases identified as haemodynamic group I by catheter study or clinical examinations have subsequently closed and the murmur disappeared.

There is a good anatomical experimental basis for expecting 25 to 30 per cent to close spontaneously, since of our cases (95) coming to necropsy with ventricular septal defect 27 per cent had a defect $5 \mathrm{~mm}$. or less. Furthermore, it has been shown experimentally in dogs that a hole $5 \mathrm{~mm}$. or less created in the septum will gradually become obliterated of its own accord over a few months.

\section{Deaths}

In 630 infants followed from the first year of life for an average of 7.5 years the deaths amounted to 6.9 per cent (Table 8). There were no deaths in the very small ventricular septal defects diagnosed by clinical evaluation and 7 per cent mortality in those that had a catheter study only and did not require surgery. However, among those that did require surgery the mortality was 26 per cent. The majority of these were in intractable failure and required either a banding operation or an attempt at direct closure. In either case the risk is high in the first 6 months of life.

Apart from the cases that died during or immediately after surgery we have not had any deaths in recent years in the children over 2 years of age with isolated ventricular septal defect due to the defect itself until they got into the adolescent age group. In the infant age group the deaths were almost entirely
TABLE 8 Deaths: average duration of followup 7 years

\begin{tabular}{lll}
\hline Group & $\begin{array}{l}\text { No. of } \\
\text { cases }\end{array}$ & Deaths \\
\hline Clinical evaluation & 318 & $(0)$ \\
Catheter study only & 208 & $15(7 \%)$ \\
Catheter and surgery & 104 & $27(26 \%)$ \\
\hline Total & 630 & $42(6.9 \%)$ \\
\hline
\end{tabular}

limited to those with a large pulmonary blood flow (>2:I) and normal or moderately raised pulmonary vascular resistance. Deaths from the Eisenmenger syndrome rarely occur before the age of Io years.

In the 295 cases born before 1955 and followed until the present time 10, or 3.4 per cent, have died in the late teens or twenties. Most of these deaths have been due to progressive pulmonary vascular disease, but two of them were associated with attempts at corrective surgery.

\section{Bacterial endocarditis}

It is very difficult to work out the true incidence of bacterial endocarditis in ventricular septal defect. If one turns to earlier data, in 1942 Gelfman and Levine found that of 31 cases of ventricular septal defect at necropsy, 43 per cent had bacterial endocarditis. These obviously occurred in the preantibiotic era.

More recent data are available which can be related to the patient years of the group followed over a period of time (Table 9).

TABLE 9 Bacterial endocarditis in ventricular septal defect

\begin{tabular}{lrl}
\hline Authors & Patient years & $\begin{array}{l}\text { Subacute } \\
\text { bacterial } \\
\text { endocarditis }\end{array}$ \\
\hline Wood (Bloomfield, 1964) 638 & 0 \\
Griffiths et al. (1964) & 837 & 4 \\
Bloomfield (1964) & 222 & I \\
Walker et al. (1965) & 1407 & 6 \\
\hline Total & 3104 & II \\
\hline
\end{tabular}

These groups taken together indicate I case of bacterial endocarditis in $\mathbf{2 8 2}$ patient years.

Shah et al. in 1966 reviewed the patient material at The Hospital for Sick Children and presented further data on the incidence of bacterial endocarditis in ventricular septal defect. In the 3 to 12 year age group covering Io years the frequency of bacterial infection was 2 per cent during that interval (or $I$ in 470 patient years).

Since then we have reviewed 295 cases of 
isolated ventricular septal defect followed during adolescence and adult life, covering an average period of Io years from 13 to 22 years. The incidence of bacterial endocarditis was I per cent ( 3 cases) or $I$ in 787 patient years.

Thus it is clear that bacterial endocarditis is an infrequent occurrence in early adult life, and furthermore when children or young adults do contract this infection the prognosis is usually good. All the cases with ventricular septal defect and bacterial endocarditis we have seen in the past Io years have recovered with medical treatment.

\section{Teenage and adult group: group D}

Table Io shows the haemodynamic categories of the teenage and adult group of 295 cases all born before 1955 and seen at some time in childhood at The Hospital for Sick Children.

TABLE IO Teenage and adult group (born before 1955)

\begin{tabular}{|c|c|c|c|c|c|c|c|}
\hline \multirow[t]{2}{*}{ Group } & \multicolumn{6}{|c|}{ Haemodynamic group } & \multirow[t]{2}{*}{ Totals } \\
\hline & $\boldsymbol{I}$ & $I I$ & $I I I$ & $I V$ & $\boldsymbol{V}$ & $V I$ & \\
\hline \multirow{3}{*}{$\begin{array}{l}\text { Clinical } \\
\text { Catheter } \\
\text { Catheter } \\
\text { and } \\
\text { surgery }\end{array}$} & 155 & $\mathbf{r}$ & 0 & ० & o & 2 & 158 \\
\hline & 72 & 2 & I & I & 0 & 23 & 99 \\
\hline & 8 & 12 & 4 & 10 & I & 3 & 38 \\
\hline $\begin{array}{l}\text { Total } \\
\text { Percentag }\end{array}$ & $\begin{array}{r}235 \\
80\end{array}$ & $\begin{array}{r}15 \\
5\end{array}$ & $\begin{array}{l}5 \\
1 \cdot 7\end{array}$ & $\begin{array}{l}\text { II } \\
3.7\end{array}$ & $\begin{array}{l}1 \\
0.2\end{array}$ & $\begin{array}{l}28 \\
9 \cdot 4\end{array}$ & $\begin{array}{l}295 \\
100\end{array}$ \\
\hline
\end{tabular}

4 per cent closed spontaneously. 3.4 per cent died (all in teens or twenties).

Incidence of bacterial endocarditis : age 3-13 years, 2 per cent; 14-22 years, I per cent.

The decade or two in which these individuals came as children to the Cardiac Clinic at The Hospital for Sick Children before 1955 produced a natural selection by our late follow-up that has eliminated those who died in the first two or three years of life, and it also eliminated those whose defects closed spontaneously in the first five or ten years of life, but it has included those whose defects had closed spontaneously since the age of 12 .

We were therefore left with the data shown in Table ro, and 158 were evaluated on clinical examination alone, 99 had catheterization, and 38 had catheterization plus surgery, for a total of 295. If one looks at the total one sees that 80 per cent are now found in category I and have small defects with low flow and low pulmonary vascular resistance. Five per cent are in group II, $I .7$ per cent in group III, 3.7 per cent in group IV, 0.2 per cent in group V, and 9.4 per cent in group VI. This latter group is composed of those who developed a high pulmonary vascular resistance with reversal of flow through the defect and they may therefore be classified as having the Eisenmenger syndrome. The outlook for them is a very limited one, and according to the data of Clarkson et al. (1968), one-third to one-half will die in the next ro years.

Thus in the teenage or adult group 80 per cent have small defects and are leading normal lives, fully active, with no functional disability. It is worth re-emphasizing that 4 per cent have closed spontaneously and only I per cent have developed bacterial endocarditis.

\section{Comparison of all groups}

Table II compares the various groups discussed in this presentation.

\section{TABLE II All ventricular septal defect} groups combined

\begin{tabular}{|c|c|c|c|}
\hline $\begin{array}{l}\text { Haemo- } \\
\text { dynamic } \\
\text { group }\end{array}$ & $\begin{array}{l}\text { Groups } A \text {, } \\
B \text {, and } C \text { at } \\
I \text { year }(630)\end{array}$ & $\begin{array}{l}\text { Groups } A \text {, } \\
B, \text { and } C \text { at } \\
7.5 \text { years }(630)\end{array}$ & $\begin{array}{l}\text { Group D } \\
\text { teen-adult } \\
(295)\end{array}$ \\
\hline $\begin{array}{l}\text { I } \\
\text { II } \\
\text { III } \\
\text { IV } \\
\text { V } \\
\text { VI }\end{array}$ & $\begin{array}{r}50.0 \% \\
26.5 \% \\
16.0 \% \\
6.0 \% \\
1.5 \% \\
0.0 \%\end{array}$ & $\begin{array}{r}71 \cdot 0 \% \\
14.0 \% \\
12 \cdot 0 \% \\
4.0 \% \\
0.6 \% \\
0.3 \%\end{array}$ & $\begin{array}{r}80.0 \% \\
5.0 \% \\
1.7 \% \\
3.7 \% \\
0.2 \% \\
9.4 \%\end{array}$ \\
\hline
\end{tabular}

Comparing children or infants seen in the first year of life with the same group an average of 7.5 years later, there is a moderately high incidence of haemodynamic group I with small defects in the first year of life, but the percentage increases at 7.5 years from 50 per cent to $7 \mathrm{I}$ per cent. Haemodynamic group II declines from 26 per cent to 14 per cent, group III declines from 16 per cent to 12 per cent, group IV from 6 per cent to 4 per cent, and group V from I. 5 per cent to 0.6 per cent. There were no cases, of course, with developed pulmonary vascular disease in the first year of life, but there is a small percentage, 0.3 per cent, by 7.5 years and nearly to per cent in the adult group. With present investigative and therapeutic measures, medical and surgical, this latter group will usually be prevented in the future by early banding of the pulmonary artery or direct closure of the defect. There will always be a few who escape medical attention and will be found to have this complication at a later date when the changes are irreversible.

Group D cannot be compared with groups A, B, and C adequately, but it can be considered as a fair representation of a long 
follow-up beginning 15-20 years ago. There is obviously a large number of young adults with small ventricular septal defects who are leading a normal life and have very little risk of developing bacterial endocarditis. They still have murmurs, but not as well heard as in childhood. Further study is needed to determine their ultimate course, but it seems likely that a significant number will continue to close spontaneously with the passage of time or remain patent but lead a normal life.

\section{References}

Ash, R. (1964). Natural history of ventricular septal defects in childhood lesions with predominant arteriovenous shunts. Fournal of Pediatrics, 64, 45.

Bloomfield, D. K. (1964). The natural history of ventricular septal defect in patients surviving infancy. Circulation, 29, 914.

Clarkson, P. M., Frye, R. L., DuShane, J. W., Burchell, H. B., Wood, E. H., and Weidman, W. H. (1968). Prognosis for patients with ventricular septal defect and severe pulmonary vascular obstructive disease. Circulation, 38, 129.

Gasul, B. M., Dillon, R. F., and Vrla, V. (1957). Further observations of the natural course of ventricular septal defect: new clinical and physiologic data (Abstr.). Circulation, 16, 885.

Gelfman, R., and Levine, S. A. (1942). The incidence of acute and subacute bacterial endocarditis in congenital heart disease. American fournal of the Medical Sciences, 204, 324.

Griffiths, S. P., Blumenthal, S., Jameson, A. G., Ellis, K., Morgan, B. C., and Malm, J. R. (I964). Ventricular septal defect: survival in adult life. American fournal of Medicine, 37, 23.

Hoffman, J. I. E., and Rudolph, A. M. (1965). The natural history of ventricular septal defects in infancy. American fournal of Cardiology, 16, 634.
Kaplan, S., Daoud, G. I., Glass, I. H., Shemtob, A., and McGuire, J. (I96I). Natural course of ventricular septal defect (Abstr.). Circulation, 24, 968.

Keith, J. D., Collins, G., Rose, V., and Kidd, L. (1970) Course and prognosis in ventricular septal defect. In Symposium on Natural History of Congenital Heart Disease, Toronto, December 1969. Charles C. Thomas, Springfield, Illinois. In Press.

_, Rowe, R. D., and Vlad, P. (Eds.) (1958). Heart Disease in Infancy and Childhood, p. 233, Macmillan, New York.

$\longrightarrow,-$, and - (1967). Heart Disease in Infancy and Childhood, 2nd ed., p. 4. Macmillan, New York.

Kidd, L., Rose, V., Collins, G., and Keith, J. (1965). The hemodynamics in ventricular septal defect in childhood. American Heart fournal, 70, 732.

Li, M. D., Collins, G., Disenhouse, R., and Keith J. D. (1969). Spontaneous closure of ventricular septal defect. Canadian Medical Association fournal, 100, 737.

Rose, V., and Keith, J. D. (1970). Toronto Heart Registry 1964. To be published.

Selzer, A. (1949). Defect of the ventricular septum: summary of twelve cases and review of the literature. Archives of Internal Medicine, 84, 798.

Shah, P., Singh, W. S. A., Rose, V., and Keith, J. D. (I966). Incidence of bacterial endocarditis in ventricular septal defects. Circulation, 34, 127.

Tyrrell, M. et al. (1970). To be published.

Walker, W. J., Garcia-Gonzalez, E., Hall, R. J., Czarnecki, S. W., Franklin, R. B., Das, S. K., and Cheitlin, M. D. (1965). Interventricular septal defect: analysis of 415 catheterized cases, 90 with serial hemodynamic studies. Circulation, 31, 54.

Wood, P. Posthumous papers. (Quoted by Bloomfield, D. K. (1964). The natural history of ventricular septal defect in patients surviving infancy. Circulation, 29, 914.) 